\title{
PENGEMBANGAN GAME MAZE BERBASIS MEDIA INTERAKTIF SESUAI TEMA UNTUK ANAK USIA 5-6 TAHUN DI TK IT IZZUDIN PALEMBANG
}

\author{
Aprilia Dwi Wulandari, Sri Sumarni , Yetty Rahelly \\ Program Studi Pendidikan Guru Pendidikan Anak Usia Dini \\ Fakultas Keguruan dan Ilmu Pendidikan, Universitas Sriwijaya \\ e-mail: apriliadwiwulandari0358@gmail.com
}

\begin{abstract}
Abstrak
Penelitian ini bertujuan untuk mengembangkan maze dalam bentuk game berdasarkan tema berbasiskan media interaktif yang valid dan praktis untuk anak usia 5-6 tahun di TK IT Izzuddin Palembang. Pengembangan game maze berbasis media interaktif sesuai tema ini menggunakan kombinasi model pengembangan ADDIE dan evaluasi Tessmer. Model pengembangan ADDIE terdiri dari 5 tahap, yaitu tahap analisis, tahap perancangan, tahap pengembangan, tahap implementasi, dan tahap evaluasi. Pada tahap evaluasi dilakukan evaluasi formatif yang dikemukakan oleh Tessmer terdiri dari empat tahap, yaitu tahap self evaluation, expert review, one-toone evaluation dan small group evaluation. Teknik pengumpulan data menggunakan observasi. Hasil expert review diperoleh rekapitulasi nilai rata-rata hasil penilaian dari para ahli materi dan untuk aspek media sebesar 3,80 (Kategori Sangat Valid) karena indikator dan materi yang sesuai dengan pembelajaran matematika anak usia 5-6 tahun yaitu kegiatan membilang dan berfikir logis. Tahap one to one evaluation didapatkan rekapitulasi hasil analisis data observasi anak terhadap penggunaan Game Maze Berbasis Media Interaktif sebesar 89,5\% (Kategori Baik Sekali). Tahap small group evaluaion didapatkan rekapitulasi hasil analisis data observasi anak terhadap penggunaan Game Maze Berbasis Media Interaktif sebesar 92,56\% (kategori baik sekali). Game Maze Berbasis Media Interaktif Sesuai Tema ini dinyatakan valid dan praktis untuk digunakan pada anak dalam berjalannya proses belajar dan pembelajaran berlangsung.
\end{abstract}

Kata Kunci: pengembangan game maze, media interaktif, anak usia 5-6 tahun

Abstract
This study aims to develop maze in the form of games based on interactive media-
based theme that is valid and practical for children aged 5- 6 years in IT TK Izzuddin
Palembang. Development of interactive media-based maze game in this theme using
combination of ADDIE development model and Tessmer evaluation. The ADDIE
development model consists of 5 stages, namely the analysis phase, the design stage,
the development stage, the implementation stage, and the evaluation stage. In the
evaluation phase, formative evaluation proposed by Tessmer consists of four stages:
self evaluation, expert review, one-to-one evaluation and small group evaluation.
Technique of collecting data using observation. The result of the expert review
obtained the recapitulation of the average score of the results of the assessment from
the material experts and for the media aspect of 3.80 (Category Highly Valid)
because theindicator and the material in accordance with the mathematics learning
of children aged 5-6 years is theactivity of calculating and logical thinking. Stage one
to one evaluation was obtained recapitulation result of analysis of observation data
of child to use Interactive Media Based Maze Game equal to 89,5\% (One Good
Category). Small group evaluaion stage was obtained recapitulation result of 
observation data of child to the use of Game Maze Based on Interactive Media equal to $92,56 \%$ (very good category). Interactive Based Media Maze Game This theme is stated valid and practical for use in children in the learning and learning process takes place.

Keywords: game development maze, interactive media, kids 5-6 years

\section{PENDAHULUAN}

Anak yang berusia 0-6 tahun disebut sebagai anak usia dini, pada rentang usia ini anak dikenal mengalami masa keemasan (The Golden Years/Golden Age) yang merupakan masa dimana anak mulai peka atau sensitif untuk menerima berbagai rangsangan. Masa ini merupakan masa yang tepat untuk meletakkan dasar-dasar pengembangan kognitif, fisik, bahasa, sosial emosional, seni, moral, dan nilainilai agama. Upaya pengembangan seluruh potensi anak usia dini harus dimulai agar pertumbuhan dan perkembangan anak tercapai secara optimal. Menurut Piaget yang dikutip oleh Sudarna (2014:12-15) Perkembangan merupakan proses yang bersifat kumulatif artinya perkembangan terdahulu akan menjadi dasar bagi perkembangan selanjutnya.

Kesadaran akan pentingnya pendidikan yang dimulai sejak usia dini telah mendorong pemerintah untuk melakukan kebijakannya, dalam hal ini Departemen Pendidikan Nasional untuk membuat sebuah direktorat baru yang bernama Direktorat Pendidikan Anak Usia Dini (PAUD). UndangUndang Republik Indonesia nomor 20 tahun 2003 tentang Sistem Pendidikan Nasional menyebutkan bahwa "Pendidikan anak usia dini adalah suatu upaya pembinaan yang ditujukan kepada anak sejak lahir sampai dengan usia enam tahun yang dilakukan melalui pemberian ransangan pendidikan untuk membantu pertumbuhan dan perkembangan jasmani dan rohani agar anak memiliki kesiapan dalam memasuki pendidikan lebih lanjut".

Pendidikan anak usia dini mengembangkan pembelajaran yang melibatkan 5 aspek kemampuan dasar yang dimiliki oleh anak salah satunya yaitu aspek perkembangan kognitif. Menurut Nugraha dikutip Elhumairoh (2015) Perkembangan kognitif adalah suatu proses berpikir berupa kemampuan otak untuk menghubungkan, menilai, dan mempertimbangkan sesuatu dalam memperoleh informasi yang meliputi kemampuan membilang dan kemampuan berhitung anak. Kemampuan kognitif ini berkembang secara bertahap, sejalan dengan perkembangan fisik dan syaraf-syaraf yang berada di pusat susunan syaraf. Menurut Piaget yang dikutip oleh Jawati (2014) menyatakan bahwa "dalam usia dini anak-anak akan melampaui tahap perkembangan bermain kognitif mulai dari bermain sensori motor atau bermain yang berhubungan dengan alat-alat panca indra seperti penglihatan, pengecap, membau, mendengar dll sampai memasuki tahap tertinggi bermain yang ada aturan bermainnya, dimana anak dituntut menggunakan nalar".

Prinsip-prinsip pembelajaran di TK harus bersifat belajar seraya bermain oleh karena itu kegiatan pembelajaran hendaknya dilakukan dengan situasi yang menyenangkan dengan menggunakan strategi, metode, materi/ bahan dan media yang menarik. Di Era-globalisasi ini perkembangan ilmu pengetahuan dan teknologi (IPTEK) bermanfaat membantu para 
pendidik dalam penyediaan media pembelajaran dan sumber belajar guna meningkatkan mutu ataupun kualitas pendidikan salah satunya berupa media interaktif (multimedia). Didalam prinsip pembelajaran di TK pelaksanaan stimulasi pada anak usia dini jika dimungkinkan dapat memanfaatkan teknologi untuk kelancaran kegiatan untuk mendorong anak menyenangi pembelajaran.

Berdasarkan hasil pengamatan dan wawancara yang peneliti lakukan pada tanggal 23 januari-15 Februari 2018 di TK IT Izzudin, TK IT Auladi Sako, dan TK Pusri kelompok B yang berusia 5-6 tahun. Di TK IT Izzudin dengan wali kelas Ibu Linda Wati dan Ibu Laisa Heryani, peneliti menemukan anak yang kesulitan mengerjakan LKA berupa Maze walaupun sebelumnya sudah diberi tahu petunjuk mengerjakannya. Ketika menemui persimpangan jalan anak masih bingung harus melewati jalan kanan atau kiri hal ini dikarenakan materi Maze jarang diberikan kepada anak, LKA Maze yang tidak sesuai dengan tema pembelajaran hari itu dan labirinnya terlalu rumit. Di TK Auladi Sako dengan wali kelas Ibu Monalisa dan Ibu Vita Syafitri pembelajaran menggunakan LKA maze juga jarang diberikan permasalahannya yang ditemuin juga sama beberapa anak masih perlu dibantu ketika mengerjakannya terlebih jika labirinnya terlalu rumit. TK Pusri dengan wali kelas Ibu Marsi Aryati memiliki kumpulan LKA berupa buku yangkhusus tentang mencari jejak yang tidak sesuai tema pembelajaran, anak terbiasa mengerjakannya namun masih dibantu jika labirin yang dilalui rumit. Permainan labirin ini melatih kognitif anak dalam berfikir logis dalam menemukan jalan keluar dari labirin tersebut seperti pendapat Subagio dkk dalam jurnalnya Labirin merupakan sebuah game puzzle yang bertujuan pemain harus menemukan jalan keluar dari sebuah pintu masuk ke satu atau lebih pintu keluar.

Dari permasalahan di atas, peneliti mencari alternatif lain dalam pembelajaran tersebut yaitu dengan berusaha menciptakan produk game maze berbasis media interaktif namun dilengkapi kegiatan membilang dengan tujuan agar anak lebih tertarik dalam mengerjakannya. Sesuai dengan penelitian yang dilakukan oleh Setianingrum dan Sudarto (2017) dengan judul "Pengaruh Permainan Maze Petualang terhadap Kemampuan Mengenal Lambang Bilangan pada KelompokA di TK Cendikia Kids School Laboratorium School Universitas PGRI Madiun". Hasil penelitian dijelaskan bahwa teknik analisis data penelitian ini menggunakan Wilcoxon Matched Pairs Test dengan rumus Thitung < Ttabel. JikaThitung lebih kecil dari Ttabel, maka Ho ditolak dan $\mathrm{Ha}$ diterima. Berdasarkan hasil analisis data diperoleh Thitung $=0$ dan Ttabel untuk N=12 dengan taraf signifikan 5\% sebesar 14, maka Thitung < Ttabel $(0<14)$. Data tersebut menunjukkan Ho ditolak dan Ha diterima. Jadi dapat disimpulkan bahwa permainan maze petualang berpengaruh terhadap kemampuan mengenal lambang bilangan kelompok A di TK Cendekia Kids School Laboratorium School Universitas PGRI Madiun.

\section{METODE PENELITIAN J enis Penelitian}

Jenis penelitian yang di ambil oleh peneliti adalah jenis penelitian pengembangan (Research and Development) dengan model ADDIE dan tahapannya sebagai berikut

\section{Prodedur Penelitian}

Tahapan awal pada penelitian ini adalah tahapan pengkajian. Analisis kebutuhan merupakan kegiatan studi pendahuluan untuk mengetahui apakah produk yang akan diciptakan ini 
dibutuhkan oleh guru atau sekolah serta apakah produk yang akan diciptakan ini sesuai dengan karakteristik anak usia 5-6 tahun. Sehingga peneliti perlu melakukan observasi awal di sekolah dengan mengamati anak dan melakukan wawancara bahwa memang benar produk yang akan diciptakan ini benarbenar dibutuhkan. Jika memang dibutuhkan barulah peneliti dapat menciptakan dan mengembangkan produk game maze berbasis media interaktif sesuai temayangberdasarkan karakteristik anak usia 5-6 tahun.

Tahap ini merupakan tahap perancangan kerangka media interaktif game yang akan dikembangkan. Komponen-komponen tersebut meliputi template, animasi, gambar, teks materi, tombol navigasi dan musik. Pembuatan desain tampilan dan pengembangan media dilakukan menggunakan aplikasi Unity. Perancangan produk pada tahapan ini tidak terlepas dari hasil analisis kebutuhan, kerangka produk yang disusun sebagai pedoman untuk tahapan pengembangan dan implementasi diantaranya :

Flowchart yang berisi tentang alur game dari media interaktif tersebut secara ringkas. Flowchart dikembangkan berdasarkan struktur navigasi yang telah dibuat di awal.

Storyboard yaitu uraian ringkas secara deskriptif yang berisi alur cerita game maze didalam media interaktif tersebut dari awal sampai akhir program.

Pengembangan adalah proses mengembangkan perangkat produk yang diperlukan dalam pengembangan atau dengan kata lain berisi kegiatan realisasi rancangan produk. Berbasis pada hasil rancangan produk dan membuat instrumen untuk mengukur kinerja produk. Proses pembuatan media pembelajaran adalah sebagai berikut.
Setelah multimedia layak digunakan maka dilakukanlah tahap implementasi. Tahap implementasi dilakukan untuk menguji penggunaan media interaktif di lapangan. Selain itu untuk mengetahui ketercapaian tujuan pengembangan produk. Sehingga dapat dilihat apakah peneliti sudah berhasil mengembangkan produk tersebut.

\section{Evaluasi}

Pada tahap ini penilaian dilakukan oleh peneliti sendiri terhadap produk yang dibuat oleh peneliti yaitu Game Maze Berbasis Media Interaktif Sesuai Tema Untuk Anak Usia 5-6 Tahun yang telah dikembangkan. Terdadpat tiga tema yaitu (1) rekreasi (2) kendaraan (3) alam semesta. Disini peneliti mengevaluasi sendiri game tersebut, dalam hal ini adalah penampilannya apakah gambarnya sudah sesuai dan jelas, apakah warnanya menarik, apakah ukuran tulisan terbaca jelas, audio terdengar jelas dan tingkat kesulitan labirin ditentukan dengan angka yang urut.

Hasil produk (Prototipe 1) yang dikembangkan atas dasar self evaluation, diberikan kepada para ahli (expert) untuk divalidasi. Pada tahap ini, validator melihat dan mengevaluasi game maze yang terdiri dari tiga tema yang telah dibuat. Uji validitas yang dilakukan adalah uji validitas content (materi) dan desain game. Hasil validasi yang berupa tanggapan/komentar dan saran-saran pada lembar validasi akan dijadikan dasar untuk merevisi game maze berbasis media interaktif sesuai tema (prototipe 1).

Pada tahap ini, produk game maze berbasis media interaktif sesuai tema diujicobakan pada anak. Peneliti akan mengambil tiga orang anak secara acak untuk mewakili populasi target yaitu anak dengan kemampuan rendah, sedang, dan tinggi. Anak tersebut akan diberikan pembelajaran dengan prototipe 1 yang sudah direvisi. Pada saat proses pembelajaran anak akan lakukan 
suatu pengamatan dengan lembar pengamatan yangtelah disediakan untuk melihat dan menilai secara langsung terhadap nalar berpikir anak atau proses terjadinya suatu pembelajaran dengan menggunakan prototipe 1 yang telah diberikan. Hal tersebut dilakukan dengan tujuan untuk mengetahui seberapa besar unsur kepraktisan game tersebut dari sudut pandang anak. Hasil pengamatan anak tersebut akan dijadikan dasar untuk merevisi produk (prototipe 1) sehingga menghasilkan prototipe 2.

Pada tahap ini, hasil dari prototipe 2 akan diujicobakan pada kelompok kecil yaitu yang terdiri dari 9 orang. Selanjutnya, anak diberikan pembelajaran berupa prototipe 2 yang sudah direvisi. Pada proses pembelajaran, anak akan diamati kembali untuk melihat dan menilai secara langsung penalaran logis anak atau proses terjadinya suatu pembelajaran dengan menggunakan game maze berbasis media interaktif sesuai tema (prototipe 2) yang digunakan dalam pembelajaran. Teknik pengumpulan data yang digunakan dalam penelitian ini yaitu:

Angket merupakan salah satu teknik pengumpulan data yang akan peneliti gunakan. Menurut arikunto (2015:42) angket/ kuesioner adalah suatu pertanyaan yang dibuat seseorang untuk diisi oleh orang yang akan diukur ( responden). Instrumen pengumpul data pada teknik ini yang digunakan peneliti adalah dengan menggunakan lembar validasi yang diberikan kepada ahli atau validator. Data yang telah didapat pada lembar validasi ini yaitu berupa tanggapan dan saran-saran yangmenjadi dasar peneliti untuk melakukan revisi pada produk awal/prototipe. Data dari hasil validasi oleh ahli kemudian didiskusikan dengan ahli itu sendiri untuk mendapatkan kejelasan informasi hasil validasi produk, sehingga peneliti bisa menggunakan data hasil validasi tersebut sebagai acuan untuk merevisi produk/prototipe sampai dinyatakan layak untuk diujicobakan. Dalam game maze berbasis media interaktif sesuai tema untuk anak proses validasinya meliputi validasi materi dan media.

Teknik pegumpulan data yang kedua adalah Observasi, menurut Sugiyono (2015: 203) Observasi digunakan untuk menilai tingkah laku dilihat dari keaktifan anak pada kegiatan pembelajaran dengan menggunakan game maze berbasis media interaktif yang dapat diamati. Pada penelitian ini, untuk mendapatkan data observasi dilakukan dengan cara melihat dan menilai secara langsung aktivitas dan tingkah laku anak selama proses pembelajaran dengan menggunakan game maze. Observasi dilakukan pada saat tahap one-to-one,small group, small group apakah sudah menghasilkan dengan baik saat menggunakan game maze berbasis media interaktif sesuai tema untuk anak. Hasil observasi dicatat oleh peneliti pada lembar observasi yang telah disediakan dengan kisi-kisi Hasil angket dengan ahli dianalisis secara deskriptif sebagai masukan untuk merevisi game. Masukan tersebut dituliskan pada lembar validasi. Lembar validasi yang diberikan kepada ahli dalam bentuk skala likert. Sugiyono (2015: 41) Skala Likert dengan menggunakan empat kategori jawaban yaitu Sangat Baik (SB), Baik (B), Kurang Baik (KB), dan Tidak Baik (TB). Selanjutnya dicari rata-rata skor tersebut dengan menggunakan rumus sebagai berikut.

$$
\mathrm{X}=\frac{\sum X}{N}
$$

(Sudjana, 2017: 109)

$$
\begin{array}{ll}
\text { Ket: } & \\
\mathrm{X} & =\text { Nilai rata-rata } \\
\sum_{\mathrm{N}} X & =\text { J umlah nilai data } \\
\mathrm{N} & =\text { Banyaknya data }
\end{array}
$$


Selanjutnya rata-rata yang didapatkan disesuaikan dengan kategori seperti yang terlihat pada Tabel 1 berikut ini.

\section{Tabel 1. Kategori Tingkat} Kevalidan

\begin{tabular}{|c|c|}
\hline Rata-Rata & Kategori \\
\hline $3,25-4,00$ & Sangat Valid \\
\hline $2,50-3,24$ & Valid \\
\hline $1,75-2,49$ & Tidak Valid \\
\hline $1,00-1,74$ & $\begin{array}{c}\text { Sangat Tidak } \\
\text { Valid }\end{array}$ \\
\hline
\end{tabular}

(Modifikasi dari Sugiyono, 2012)

Hasil observasi terhadap anak selama ujicoba pada tahap one-to-one evaluation, small group evaluation dan field test digunakan untuk melihat tingkah laku anak pada saat proses pembelajaran menggunakan game maze berbasis media interaktif sesuai tema untuk anak ini. Data hasil obsevasi disajikan dalam bentuk tabel, kemudian menghitung nilai hasil observasi dengan menggunakan rumus sebagai berikut.

Nilai Persentase

$$
=\frac{\text { Skor Perolehan }}{\text { Skor Maksimal }} \times 100 \%
$$

(Sunarti \& Rahmawati, 2014: 191)

Nilai observasi dikonversikan ke dalam kategori yang ditetapkan seperti pada Tabel 2 di bawah ini.

Tabel 2. Kategori Nilai Hasil Observasi Anak Terhadap Penggunaan Game Maze Berbasis Media Interaktif Sesuai Tema Untuk Anak Usia 5-6 Tahun

\begin{tabular}{|c|c|}
\hline Skor (\%) & Kategori \\
\hline $82-100$ & BSB \\
\hline $63-81$ & BSH \\
\hline $44-62$ & $\mathrm{MB}$ \\
\hline
\end{tabular}

\begin{tabular}{|c|c|}
\hline 19-43 & BB \\
\hline \multicolumn{2}{|c|}{ (Amirono \& Daryanto, 2016: 126) } \\
\hline
\end{tabular}

\section{HASIL DAN PEMBAHASAN Hasil}

Hasil penelitian yang berjudul pengembangan game maze berbasis media interaktif sesuai tema dilakukan dengan 5 tahap yaitu (1) Analisi (Analyze) (2) Perancangan (Design) (3) Pengembangan (Development) (4) Implementasi (Implementation) (5) Evaluasi (Evaluation). Peneliti mengembangkan game maze berbasis media interaktif yang sesuai tema. Berikut ini adalah uraian tahapan dalam pengembangan.

Analisis kebutuhan dan perkembangan dilakukan untuk mengetahui dan mengidentifikasi perkiraan kebutuhan dan perkembangan anak, yaitu dengan melihat indikator pencapaian perkembangan kognitif anak usia 5-6 tahun dan mendeskripsikan kriteria game maze berbasis media interaktif untuk anak yang disesuaikan dengan tema yang ada di kurikulum.

Garis besar materi pembelajaran LKA Maze dijadikan dasar untuk merancang game maze dalam bentuk media interaktif. Game maze ini bermuatkan materi bilangan angka 1-30 secara urut. Didalam game tersebut terdapat tiga tema dari salah satu tema pembelajaran yang ada di semester II, langkah yang pertama yang dilakukan adalah mendesain maze dan disesuaikan tingkat kesukarannya dari jumlah urutan angka ditiap level selanjutnya game diberi gambaran atau properti pendukung seperti gambar perkantoran ataupun taman untuk memperindah tampilannya, game ini juga dilengkapi dengan backsound dan audio untuk memperjelas tampilan pertanyaan yang dibuat. Game yang telah didesain sesuai rancangan dibuat menggunakan aplikasi Unity.

Setelah melakukan rancangan game maze menggunakan aplikasi unity, 
langkah selanjutnya adalah produksi prototipe. Peneliti memproduksi tiga tema dimana disetiap tema terdapat tiga level dengan tingkat kesulitan yang berbeda ditentukan dengan urutan bilangan angka. Game maze berbasis media interaktif ini menggunakan salah satu tema pembelajaran semester II yaitu sebagai berikut. (1) Tema Rekreasi, (2) Tema Kendaraan, dan (3) Tema Alat Komunikasi. Hasil keseluruhan tahap pengembangan ini adalah prototipe 1 . Pada tahap pengembangan juga disiapkan perangkat evaluasi yang digunakan untuk menilai urutan bilangan angka di content/materi dan desain game maze dimedia. Perangkat evaluasi berupa lembar validasi content/materi, media dan lembar observasi untuk menilai aktivitas anak terhadap penggunaan game maze berbasis media interaktif sesuai tema. Sebelum digunakan, perangkat evaluasi tersebut terlebih dahulu diperiksa oleh dosen pembimbing.

Dari tampilan maze yang dibuat bermaterikan urutan bilangan angka yang dimuat dalam bentuk game sesuai tema yang akan ditampilkan melalui media interaktif disebut sebagai prototipe 1. Selanjutnya, Prototipe 1 dilakukan tahap self evaluation. Setelah self evaluation dilakukan kemudian lanjutketahap expert review yang terdiri dari ahli content/materi dan media. Selain itu, dilakukan uji coba one-to-one evaluation pada 3 orang anak kelompok B dan small group evaluation pada 9 orang anak kelompok B. Hasil dari masing-masing tahap evaluasi sesuai dengan model evaluasi formatif Tessmer yaitu sebagai berikut.

Expert Review merupakan tahap untuk melihat validitas secara content/materi dan gamemazeberbasis media interaktif yang dikembangkan oleh peneliti. Tahap ini bertujuan untuk mendapatan materi dan media pada game maze berbasis media interaktif sesuai tema yang valid. Menurut
Hayuningtyas dan Widiyanto (2015:6) Valid adalah tindaknya suatu alat tergantung kemampuan alat tersebut untuk mengukur objek tersebut dengan cermat dan tepat. Hasil rekapitulasi penilaian validator materi dan desain media dapat dilihat pada Tabel 3 berikut ini.

Tabel 3. Rekapitulasi Hasil Penilaian Validator

\begin{tabular}{|c|c|c|c|c|}
\hline \multirow{2}{*}{$\begin{array}{c}\text { N } \\
\text { o }\end{array}$} & $\begin{array}{c}\text { Valida } \\
\text { si }\end{array}$ & $\begin{array}{c}\text { Tem 1 } \\
\text { a } \\
\text { Rek } \\
\text { reas } \\
\text { i }\end{array}$ & $\begin{array}{c}\text { Tema } \\
\mathbf{2} \\
\text { Kend } \\
\text { araa } \\
\text { n }\end{array}$ & $\begin{array}{c}\text { Tema } \\
\mathbf{3} \\
\text { Alat } \\
\text { Komu } \\
\text { nikasi }\end{array}$ \\
\hline 1 & $\begin{array}{c}\text { Content } \\
\text { / materi }\end{array}$ & 3,75 & 3,75 & 3,75 \\
\hline 2 & Media & 3,82 & 3,88 & 3,88 \\
\hline Rata-Rata & $\mathbf{3 , 7 8}$ & $\mathbf{3 , 8 1}$ & $\mathbf{3 , 8 1}$ \\
\hline \multicolumn{2}{|c|}{ Jumlah } & \multicolumn{3}{|c|}{$\mathbf{1 1 , 4}$} \\
\hline \multicolumn{2}{|c|}{$\begin{array}{c}\text { Hasil } \\
\text { Nilai }\end{array}$} \\
Rata-Rata
\end{tabular}

didapatkan bahwa rekapitulasi hasil penilaian validasi expert review untuk aspek content/materi dan aspek media dengan nilai rata-rata Tema 1 (Rekreasi) sebesar 3,78 Tema 2 (Kendaraan) sebesar 3,81 dan Tema 3 (Alat Komunikasi) sebesar 3,81 dengan total jumlah ketiganya sebesar 11,4 dan hasil nilai rata-rata sebesar 3,8 (Kategori Sangat Valid). Penilaian aspek content/materi pada Tema 1 (Rekreasi) didapatkan jumlah skor sebesar 45 dengan skor rata-rata 3,75 (Kategori Sangat Valid), Tema 2 (Kendaraan) didapatkan jumlah skor sebesar 45 dengan skor rata-rata 3,75 (Kategori Sangat Valid) dan Tema 3 (Alat Komunikasi) didapatkan jumlah skor sebesar 45 dengan skor rata-rata 3,75 (Kategori Sangat Valid). Untuk penilaian aspek Media pada Tema 1 (Rekreasi) didapatkan skor 65 dengan skor rata-rata 3,82 (Kategori Sangat 
Valid). Pada Tema 2 (Kendaraan) didapatkan skor 66 dengan skor ratarata 3,88 (Kategori Sangat Valid) dan Tema 3 (Alat Komunikasi) didapatkan skor 66 dengan skor rata-rata 3,88 (Kategori Sangat Valid). Hasil komentar validasi expert review dapat dilihat pada tabel 4 .

Tabel 4. Komentar Validator pada Tahap Expert Review

\begin{tabular}{|c|c|c|c|}
\hline No & $\begin{array}{l}\text { Valida } \\
\text { tor }\end{array}$ & Komentar & $\begin{array}{l}\text { Tanggapa } \\
\text { n Peneliti }\end{array}$ \\
\hline 1 & $\begin{array}{c}\text { Validator } 1 \\
\text { (Content/ } \\
\text { materi) }\end{array}$ & $\begin{array}{l}\checkmark \text { Ubah pernyataan } \\
\text { instrument. }\end{array}$ & $\begin{array}{c}\text { Telah } \\
\text { diperbaiki }\end{array}$ \\
\hline 2 & $\begin{array}{l}\text { Validator } \\
2 \text { (Media) }\end{array}$ & $\begin{array}{ll}\checkmark & \text { Dilengkapi dengan } \\
\text { backsound yang } \\
\text { disesuaikan dengan } \\
\text { tema. } \\
\checkmark \text { Dilengkapi dengan } \\
\text { pertanyaan setelah } \\
\text { menyelesaikan setiap } \\
\text { level yang dilewati. } \\
\checkmark \text { Ditambah hiasan agar } \\
\text { tampilan lebih menarik } \\
\checkmark \text { Ubah ukuran tampilan } \\
\text { avatar (sepeda) jangan } \\
\text { terlalu kecil. } \\
\checkmark \text { Ditambah kolom Back } \\
\text { dan Next }\end{array}$ & $\begin{array}{c}\text { Telah } \\
\text { diperbaiki }\end{array}$ \\
\hline
\end{tabular}

Setelah dilakukan tahap expert review terhadap prototipe 1, selanjutnya dilakukan tahap one-to-one evaluation yang bertujuan untuk melihat kepraktisan prototipe 1 yang telah divalidasi oleh ahli. Menurut Kampus Besar Bahasa Indonesia (KBBI) dalam Poetra (2016:794) praktis adalah mudah dan senang memakainnya (menjalankan dan sebagainya). Tahap ini melibatkan tiga orang anak dan mereka secara bersamaan menggunakan prototipe 1 . Pada saat proses pembelajaran menggunakan prototipe 1, mereka diobservasi oleh peneliti yang bertujuan untuk melihat dan menilai secara langsung aktivitas anak terhadap prorotipe 1. Pada tahap One-to-One dipilih 3 orang anak secara acak didalam kelas tersebut dengan kriteria anak Tinggi, Sedang dan Rendah. Data observasi yang diambil dilihat dari indicator pencapaian anak dengan materi pembelajaran yang sesuai dengan kurikulum 2008 revisi. Game maze ini dibuat dengan tiga tema pembelajaran disemester II (Dua) yaitu sebagai berikut: Tema 1 (Rekreasi), tema 2 (Kendaraan) dan Tema 3 (Alat Komunikasi) Rekapitulasi hasil analisis data observasi anak terhadap game maze berbasis media interaktif pada tahap One-to-One Evaluation dapat dilihat pada Tabel 5 berikut ini:

Tabel 5. Rekapitulasi Hasil

Analisis Data Observasi Anak

Terhadap Game Maze Berbasis

Media Interaktif Pada Tahap

One-To-One Evaluation

\begin{tabular}{|c|c|c|}
\hline No & Tema & $\begin{array}{c}\text { Nilai } \\
\text { rata- } \\
\text { rata }\end{array}$ \\
\hline 1 & $\begin{array}{c}\text { Tema 1 } \\
\text { (Rekreasi) }\end{array}$ & $86 \%$ \\
\hline 2 & Tema 2 (Kendaraan) & $91,3 \%$ \\
\hline 3 & $\begin{array}{c}\text { Tema 3 } \\
\text { (Alat Komunikasi) }\end{array}$ & $91,3 \%$ \\
\hline \multicolumn{2}{|c|}{ Jumlah } & $268,6 \%$ \\
\hline \multicolumn{2}{|c|}{ Rata-rata (\%) } & $89,5 \%$ \\
\hline \multirow{2}{*}{ Kategori } & $\begin{array}{c}\text { Sangat } \\
\text { Baik }\end{array}$ \\
\hline
\end{tabular}

Berdasarkan data dari Tabel diatas diperoleh nilai persentase rata-rata hasil observasi anak terhadap pengunaan Game Maze Berbasis Media Interaktif pada tahap One to one adalah sebesar 89,4\% (kategori Sangat Baik). Pada Tema 1 (Rekreasi) Nisa mendapat skor 100, Abidah mendapat skor 91 dan Owie mendapat skor 83, total jumlah skor pada tema ini 271 dengan persentase nilai rata-rata sebesar 91,3\%. Pada Tema 2 (Kendaraan) Nisa mendapat skor 100, Abidah mendapat skor 83 dan Owie mendapat skor 75, total jumlah skor pada tema ini 258 dengan persentase nilai rata-rata $86 \%$. Pada Tema 3 (Alat Komunikasi) Nisa mendapat skor 100, Abidah mendapat skor 91 dan Owie mendapat skor 83, total jumlah skor pada tema ini 274 dengan persentase nilai rata-rata sebesar 91,3\% sehingga dapat disimpulkan bahwa penggunaan Game Maze Berbasis Media Interaktif 
dengan 3 Tema pada tahap small group evaluation memiliki kriteria sangat baik dalam artian game sangat mudah digunakan dan dapat digunakan sebagai media pembelajaran interakatif oleh guru untuk anak sehingga telah menjadi produk yang baik dari segi kelayakan dan kepraktisan.

Pada tahap small group evaluation, prototipe 2 diujicobakan kepada 9 orang anak secara kelompok. Pada akhir uji coba small group evaluation, anak diobservasi kembali keaktifannya terhadap prototipe 2 yang sedang dikembangkan. Hasil observasi anak terhadap penggunaan game maze berbasis media interaktif sesuai tema dapat dilihat pada Tabel 6 berikut ini.

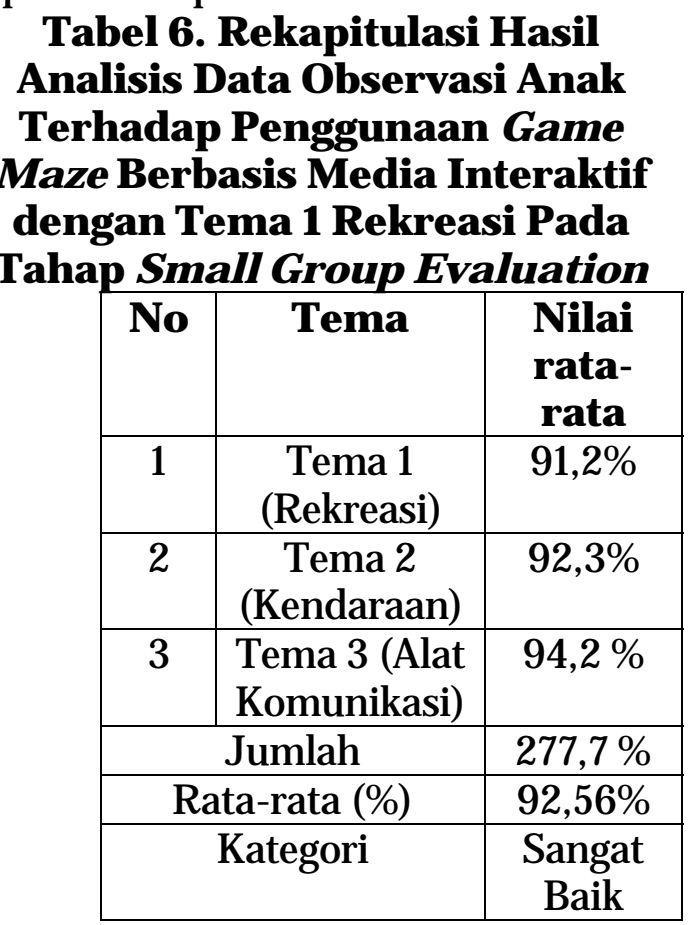

Berdasarkan data dari tabel diatas diperoleh nilai persentase rekapitulasi hasil analisis observasi anak terhadap penggunaan Game Maze Berbasis Media Interaktif pada tahap small group evaluation sebesar 91,2\% (kategori sangat baik). Pada Tema 1 (Rekreasi) WI dan AI mendapat skor 100 sedangkan ZK, RR, AZR, FTH dan AYL mendapat skor 91 sementara HY dan RZ mendapat skor 83, total jumlah nilai 821 dengan persentase nilai rata-rata sebesar $91,2 \%$.
Pada Tema 2 (Kendaraan) HY, WI, AI dan AZR mendapat skor 100 sedangkan ZKdan AYL mendapat skor 91 sementara RZ, RR dan FTH mendapat skor 83, total jumlah nilai 831 dengan persentase nilai rata-rata sebesar 92,3\%. Pada Tema 3 (Alat Komunikasi) HY, ZK, WI, AI, dan AZR mendapat skor 100 sedangkan RR dan AYL mendapat skor 91 sementara RZ dan FTH mendapat skor 83, total jumlah nilai 848 dengan persentase nilai ratarata sebesar 94,2\% sehingga dapat disimpulkan bahwa penggunaan Game Maze Berbasis Media Interaktif dengan 3 Tema tersebut pada tahap small group evaluation memiliki kriteria sangat baik dalam artian game sangat mudah digunakan dan dapat digunakan sebagai media pembelajaran interakatif oleh guru untuk anak sehingga telah menjadi produk yang baik dari segi kelayakan dan kepraktisan.

\section{Pembahasan}

Penelitian Pengembangan ini bertujuan untuk mengembangkan game maze berbasis media interaktif sesuai tema untuk anak usia 5-6 tahun di TK IT Izzuddin Palembang. Dalam hal ini peneliti mengembangkan maze dengan tiga tema berbasis media interaktif pada semester II diantaranya sebagai berikut: (1) Tema Rekreasi, (2) Tema Kendaraan dan (3) Tema Alat Komunikasi, disetiap tema terdapat tiga level. Penelitian ini dilakukan pada tanggal 23-25 April 2018 dengan subjek penelitian anak kelompok B1 di TK IT Izzuddin Palembang dan objek penelitian berupa game maze berbasis media interaktif sesuai tema. Penelitian ini menggunakan kombinasi model pengembangan ADDIE dan model evaluasi formatif Tessmer. Model pengembangan ADDIE terdiri dari lima tahap, yaitu tahap analisis, tahan perancangan, tahap pengembangan, tahap implementasi dan tahap evaluasi. Pemilihan model pengembangan ADDIE dalam penelitian ini karena model pengembangan ADDIE merupakan 
salah satu model yang berorientasi pada produk khususnya untuk memproduksi media berupa media interaktif atau multimedia. Selanjutnya, untuk tahap evaluasi digunakan model evaluasi Tessmer yang terdiri dari empat tahap, yaitu tahap self evaluation, expert review, one-to-one evaluation, dan small group evaluation.

Penelitian ini, pada evaluasi dilakukan sampai tahap small group dengan tujuan untuk menguji kevalidan dan kepraktisan produk game maze berbasis media interaktif sesuai tema. Pada tahap analisis kebutuhan merupakan kegiatan studi pendahuluan untuk mengetahui apakah produk yang akan diciptakan ini dibutuhkan oleh guru atau sekolah sesuai dengan perkembangan anak. Dalam hal ini, peneliti akan mengembangkan game maze berbasis media interaktif sesuai tema untuk anak usia 5-6 tahun di TK IT Izzuddin Palembang dengan merujuk pada tujuan Kurikulum 2013.

Materi yang diberikan sesuai dengan pembelajaran maze pada umumnya sebagai bentuk meningkatkan minat belajar anak dan pembelajaran mengenai bilangan angka. Selanjutnya, tidak adanya pembelajaran yang bervariasi dalam memberikan materi pembelajaran maze, hanya berupa LKA dengan menggunakan pensil. Untuk itu diperlukan sebuah game maze berbasis media interaktif sesuai tema yang dapat menampilkan pembelajaran yang menyenangkan bagi anak sehingga anak lebih tertarik dan dapat mempelajarinya bilangan angka dengan cara yang menarik. Oleh karena itu, peneliti mengembangkan game maze yang terdiri dari materi bilangan angka kemudian ditayangkan melalui media interaktif yang menarik bagi anak.

Setelah dilakukan tahap perancangan, selanjutnya peneliti melakukan tahap pengembangan. Tahap pengembangan terdiri dari tiga tahap yaitu pengembangan topik, penyusunan draft dan produksi prototipe. Pada tahap ini juga peneliti menyiapkan perangkat evaluasi. Sebelum digunakan perangkat evaluasi terlebih dahulu dikonsultasikan dengan dosen pembimbing. Hasil dari tahap pengembangan ini adalah prototipe 1. Game maze yang telah dikembangkan kemudian divalidasi oleh para ahli (expert review). Tahap expert review ini bertujuan untuk mengetahui materi dan desain game maze berbasis media interaktif sesuai tema yang valid. Dalam lagu-lagu islami berdasarkan tema berbasis video ini, validasi ahli meliputi validasi content/materi dan desain game maze berbasis media interaktif sesuai tema. Prototipe 1 yang telah didesain kemudian dikonsultasikan dengan dosen pembimbing skripsi dan kemudian divalidasi oleh ahli.

Secara keseluruhan, rekapitulasi hasil penilaian validasi expert review untuk aspek content/materi dan aspek media dengan nilai rata-rata Tema 1 (Rekreasi) sebesar 3,78 Tema 2 (Kendaraan) sebesar 3,81 dan Tema 3 (Alat Komunikasi) sebesar 3,81 dengan total jumlah ketiganya sebesar 11,4 dan hasil nilai rata-rata sebesar 3,8 (Kategori Sangat Valid).

Dengan demikian, game maze yang dikembangkan peneliti dapat digunakan pada tahap uji coba selanjutnya. Berdasarkan saran dari validator maka terdapat beberapa revisi dari prototipe 1 . Selanjutnya, game maze berbasis media interaktif sesuai tema yang telah divalidasi kemudian diujicoba pada tahap one-to-one evaluation. Tahap oneto-one evaluation bertujuan untuk melihat kepraktisan prototipe 1 yang telah divalidasi oleh ahli. Tahap ini melibatkan tiga orang anak dan mereka secara bersamaan mengaplikasikan game maze tersebut, pada saat anak melewati setiap 1 level terdapat soal yang harus dijawab anak dengan cara memilih angka yang tepat begitupun dilevel selanjutnya. Tahap ini terlebih dahulu peneliti tayangan dengan menjelaskan 
petunjuk permainannya, kemudian anak diperintahkan untuk mengaplikasikan atau memainkannya. Setelah anak menggunakan prototipe 1, peneliti mengobservasi anak pada saat pembelajaran yang bertujuan untuk melihat penilaian mereka terhadap prototipe 1.

Rekapitulasi hasil analisis data observasi anak terhadap pengunaan game maze berbasis media interaktif sesuai tema pada tahap one-to-one evaluation adalah sebesar 89,5\% (kategori Sangat Baik) sehingga dapat disimpulkan bahwa penggunaan game maze berbasis media interaktif sesuai tema tergolong praktis. Hasil revisi dari prototipe 1 didapatkan prototipe 2 .

Untuk melihat kepraktisan game maze berbasis media interaktif sesuai tema dilakukan uji coba prototipe 2 pada anak dalam tahap small group evaluation. Tahap ini dilaksanakan untuk melihat kepraktisan protipe 2. Uji coba prototipe 2 ini dilakukan kepada 9 orang anak kelompok B1 di TK IT Izzuddin Palembang. Tahap ini juga peneliti tayangan dengan menjelaskan petunjuk permainannya, kemudian anak diperintahkan untuk mengaplikasikan atau memainkannya. Pada uji coba di tahap small group evaluation, anak diobservasi kembali. Rekapitulasi hasil analisis data observasi anak terhadap pengunaan game maze berbasis media interaktif sesuai tema pada tahap small group evaluation adalah sebesar 92,56\% (kategori Sangat Baik).Hal ini berarti game maze berbasis media interaktif sesuai tema yang digunakan untuk anak usia 5-6 tahun memiliki kepraktis terhadap pemahaman anak. Berdasarkan deskripsi dan analisis data hasil penelitian didapatkan bahwa produk game maze yang dikembangkan sangat valid dan praktis terhadap pemahaman anak, sehingga dapat digunakan sebagai media pembelajaran dalam pembelajaran sehari-hari khususnya pembelajaran aspek kognitif anak usia 5-6 tahun.

\section{KESIMPULAN}

Berdasarkan penelitian yang telah dilakukan tentang pengembangan game maze berbasis media interaktif sesuai tema untuk anak usia 5-6 tahun di TK IT Izzudin Palembang dapat disimpulkan valid dan praktis. Teruji Kevalidannya berdasarkan hasil validasi para ahli (expert review) yang terdiri dari ahli content/materi dan media sehingga game maze berbasis media interaktif sesuai tema ini layak digunakan sebagai media pembelajaran dalam aspek kognitif anak yaitu memahami dan membilang angka. Hal ini dapat diketahui dari nilai rata-rata hasil observasi validasi Expert Review pada aspek content/materi dan aspek media sebesar 3,80 (Kategori Sangat Valid) untuk menguji kepraktisan game maze berbasis media interaktif dilihat dari kemudahan dalam menggunakannya. Berdasarkan Rekapitulasi hasil analisis data observasi anak terhadap pengunaan game maze berbasis media interaktif sesuai tema pada tahap oneto-one evaluation adalah sebesar 89,5\% (kategori Sangat Baik). Rekapitulasi hasil analisis data observasi anak terhadap pengunaan game maze berbasis media interaktif sesuai tema pada tahap small group evaluation adalah sebesar 92,56\% (Kategori Sangat Baik). Berdasarkan hasil validasi para ahli (expert review), one-to-one evaluation dan small group dapat dinyatakan bahwa game maze berbasis media interaktif sesuai tema yang dikembangkan telah teruji kevalidan dan kepraktisannya.

\section{UCAPAN TERIMA KASIH}

Penulis mengucapkan terima kasih kepada Ibu Dr. Sri Sumarni, M.Pd dan Dra. Yetty Rahelly, M.Pd, Ph. D sebagai pembimbing atas segala bimbingan yang telah diberikan dalam penulisan 
jurnal ini. Penulis juga mengucapkan terima kasih kepada Bapak Prof. Sofendi, M.A., Ph.D., Dekan FKIP Unsri., Ibu Dr. Sri Sumarni, M.Pd., Ketua J urusan Ilmu Pendidikan dan Ibu Dra. Syafdaningsih, M.Pd, Ketua Program Studi Pendidikan Guru Pendidikan Anak Usia Dini yang telah memberikan kemudahan dalam pengurusan administrasi penulisan jurnal ini. Lebih lanjut penulis juga mengucapkan terima kasih kepada DIKTI yang telah memberikan beasiswa selama penulis mengikuti pendidikan.

\section{DAFTAR PUSTAKA}

Ahmad dan Wahyu. (2017). Penerapan Algoritma A Star (A*) Pada Game Petualangan Labirin Berbasis Android. Jurnal Ilmu Komputer dan Informatika, 2(3): 58

Ambarita, Henny Maryati. (2015). Pengembangan Multimedia Pembelajaran Interaktif Materi Berhitung UntukAnak KelompokA TK Teruna Bangsa. Jurnal Pendidikan Guru Pendidikan Anak Usia Dini, 5(4): 1

Apriyanto dan Ishak. (2016). Pembuatan Game Menggunakan Aplikasi Construct 2 Berbasis Online. J urnal Elektronik Sistem Informasi dan Komputer, 2(2):

Asmawati dan Luluk. (2014). Perencanaan Pembelajaran PAUD. Bandung: PT. REMAJA ROSDAKARYA

Aziz dan Safrudin. (2017). Strategi Pembelajaran Ajaran Aktif Anak Usia Dini. Yogyakarta: Kalimedia

Azman, Nur ddk. (2014). Intisari Matematika berdasarkan kurikulum terbaru. Bandung: Fokus Media
Cahyani, Ayu dkk. (2014). Model Pembelajaran Quantum Melalui Permainan Tradisional Untuk Meningkatkan Kognitif Anak Kelompok B TK Kumara Jaya Denpasar. e-J ournal PG-PAUD Universitas Pendidikan Ganesha, 1(2):

Constantina dan Rachma. (2015). Pengaruh Permainan Maze Angka terhadap Kemampuan Mengenal Lambang Bilangan 1-10 pada Anak Kelompok A. Jurnal Pendidikan Unesa, 2(4):1

Damayanti, Yasinta Nina. (2015). Peningkatan Kemampuan Membilang Melalui Media Kartu Bergambar pada Anak Kelompok B1 TK PKK 37 Dodogan J atimulyo Dlingo Bantul. J urnal Pendidikan Guru PAUD S1, 2(4):1

Daryanto. (2016). Media Pembelajaran Peranannya Sangat Penting dalam Mencapaian Tujuan Pembelajaran. Yogyakarta: Gava Media

Ekawati dan Achmad. (2015). Pemanfaatan Teknologi Game Untuk Pembelajaran Mengenal Ragam Budaya Indonesia Berbasis Android. Jurnal Link ISSN 1858-4667, 1(22):31

Erdisna dan Arif. (2015). Perancangan Media Pembelajaran Interaktif Berbasis Multimedia Untuk Taman Kanak-Kanak Menggunakan Adobe Flash CS3. J urnal Komtekinfo Fakultas Ilmu Komputer, 1(2): 29 